\title{
Plasmid profile and curing analysis of Pseudomonas aeruginosa as metal resistant
}

\author{
C. Edward Raja; *G. S. Selvam \\ Department of Biochemistry, School of Biological Sciences, Centre for excellence in Genomic Sciences, Madurai \\ Kamaraj University, Madurai 625 021, India
}

Received 4 August 2008; revised 12 December 2008; accepted 28 January 2009; available online 1 March 2009

\begin{abstract}
The isolate Pseudomonas aeruginosa exhibited resistance to heavy metals such as cadmium, chromium, nickel and lead. Plasmid DNA was isolated from P. aeruginosa and designated as $\mathrm{pBC} 15$. The size of the plasmid DNA was approximately $23 \mathrm{~kb}$. Escherichia coli $\mathrm{DH} 5 \alpha$ was transformed with plasmid pBC15 subsequired resistance to nickel and ampicillin. The same size of the plasmid was isolated from E. coli transformant and separated on $0.7 \%$ agarose gel electrophoresis. The restriction analysis of $\mathrm{pBC} 15$ showed that the plasmid DNA has single site for Bam HI and Eco RI and three sites for Xho I which were compared with $1 \mathrm{~Kb}$ DNA and $\lambda$ Hind III digest molecular markers. Therefore, the size of the plasmid DNA of pBC15 was confirmed to be $23 \mathrm{~kb}$. Curing was carried out by ethidium bromide, acridine orange, novobiocin, sodium dodechyl sulphate and elevated temperature $\left(40{ }^{\circ} \mathrm{C}\right)$. Transformation and curing results suggest that nickel and ampicillin resistance gene was conferred by plasmid DNA. Cadmium resistant gene was present on chromosomal DNA along with the gene for chromium resistance. Lead resistance gene was shown to be present on the chromosomal DNA rather than the plasmid DNA as the cured and uncured cultures remained similar in lead resistance. Therefore, the ability of $P$. aeruginosa resistant to nickel and ampicillin is plasmid mediated and transferable to other strains whereas cadmium, chromium and lead could be chromosomal encoded. The heavy metal and antibiotic resistances of $P$. aeruginosa can be used to exploit for clean up industrial wastewater and bioremediation of heavy metal contaminated soil.
\end{abstract}

Keywords: Antibiotics, E. coli, heavy metals, wastewater, bioremediation

\section{INTRODUCTION}

Environmental pollution with toxic heavy metals is spreading throughout the world along with industrial progress. The important toxic metals cadmium, nickel and lead find its way to the water bodies through wastewater (Ajmal et al., 1998). Hazardous characteristics of the pollutants cause renal dysfunction, bone degeneration, liver, lungs and blood damage (Ebdon et al., 2001). Cadmium is the most dangerous metal ion for human health due to its hazardous characteristics and non-biodegradability. It has been reported that cadmium damages the cells by a broad spectrum of effects on cell metabolism. It is known to bind with essential respiratory enzymes (Nies, 2003), cause oxidative stress (Banjerdkji et al., 2005) and inhibits DNA repair (Jin et al., 2003). Nickel is the most abundant heavy metal contaminants of the environment due to its release during mining and smelting practices (Prasad and Strazalka, 2000). Nickel is required as an essential co-factor in several bacterial

ه*Corresponding Author Email: drselvamgsbiochem@yahoo.com Tel.: +91 452245 9213; Fax: +91 4522459181 enzymes, which carry out metabolic functions (Mulrooney and Hausinger, 2003), but it disrupts processes when it is present in excess (Babich and Stotzky, 1983). Lead is a hazardous waste and is highly toxic to humans, plants and animals (Low et al., 2000). In humans chronic lead exposure produces neurotoxicity, anaemia and kidney damage and acute lead toxicity can be fatal (Rensing et al., 1998). Similarly chromium (VI) is the toxic form of chromium released during many industrial processes, including electroplating, leather tanning and pigment manufacture (Prasenjit and Sumathi, 2005). Chromium (VI) is extremely toxic, mutagenic (Cheng and Dixon, 1998), carcinogenic (Shumilla et al., 1999) and terartogenic (Asmatullah et al., 1998) which effects on biological systems. The role of microorganisms in bioremediation is important because of their ability to degrade hazardous compounds into harmless ones. Pseudomonas species are found ubiquitously in nature and abundantly in water, soil and plants. Many species of Pseudomonas are metabolically versatile and a large 
number of organic compounds can be used as unique carbon and energy sources (Romling, 1994). This versatility allows them to be present in many environments as natural autochthonous microflora with a high potential for bioremediation of pollutants (Rossello-Mera, 1994). The ability of a genetic marker for transfering from one bacterium to another through conjugation or transformation provides a good presumptive evidence for the involvement of plasmid, particularly if the frequency of transfer is high. Moreover, loss of certain genetic markers as a result of treatment of bacterial cell to plasmid curing agents also suggests for the plasmidial nature of the marker (Mesas et al., 2004). Some heavy metal resistance determinants move from plasmid to chromosome (or in the reverse direction). This makes plasmid encoding heavy metal resistance an important aspect of environmental research. The plasmid can be the source of resistance genes for cloning purpose which have potential use in biotechnology such as the manufacture of biosensors and bioremediation processes (Collard et al., 1994). An attempt was made to identify plasmid or chromosome mediated determinants of $P$. aeruginosa to confer resistance to heavy metals and antibiotics.

The isolate $P$. aeruginosa employed in the present study was isolated from oil mill industry waste water in Virudhunagar District, South India. This research was carried out from September 2006 to November 2007.

\section{MATERIALS AND METHODS}

Pseudomonas aeruginosa strain BC15 isolated from oil mill industry wastewater sample was identified and characterized (Edward Raja et al., 2006). Plasmid DNA from bacterial strains was isolated using alkaline lysis method (Sambrook et al., 1989). P. aeruginosa plasmid DNA was extracted with STE solution. The size of the plasmid DNA was determined by $0.7 \%$ agarose gel electrophoresis with $\lambda$ Hind III digest used as marker. The plasmid DNA was used to transform E. coli DH5 $\alpha$ by transformation using calcium chloride. The transformation procedure was adopted as described by Sambrook et al. (1989). The transformants were selected on LB agar plates containing nickel (100 $\mu \mathrm{g} / \mathrm{mL})$ or ampicillin $(100 \mu \mathrm{g} / \mathrm{mL})$. Restriction analysis of BC15 plasmid DNA was digested with restriction enzymes such as Bam HI, Eco RI and Xho I. The digestion products were analyzed by electrophoresis in $1 \%$ agarose gel and the size of the plasmid DNA fragment was determined with that of known molecular size marker. The overnight culture of $P$. aeruginosa was inoculated in Luria-Bertani (LB) medium supplemented with a curing agents such as ethidium bromide $0.5 \mathrm{mM}$, followed by acridine orange $0.5 \mathrm{mM}$, novobiocin $100 \mu \mathrm{M}, 10 \%$ sodium dodechyl sulphate (SDS) and elevated temperature at $40^{\circ} \mathrm{C}$ were incubated for $48 \mathrm{~h}$. The culture was serially diluted and plated on LB agar plates. The isolated colonies were tooth picked and transferred to Luria-Bertani (LB) agar plates with and without $100 \mu \mathrm{g} / \mathrm{mL}$ nickel. The colonies which were unable to grow on the LB agar plates supplemented with nickel were counted and their numbers were compared with those present in the LB agar plates to verify plasmid curing. Antimicrobial susceptibility of wild type, cured, transformant and E. coli DH5 $\alpha$ was performed on Mueller-Hinton agar plates by disc diffusion method (Bauer et al., 1966) and using antimicrobial discs. The zone of inhibition was observed after $48 \mathrm{~h}$ of incubation at $37^{\circ} \mathrm{C}$. The following antibiotics were used in the present study: Ampicillin $(10 \mu \mathrm{g})$, tetracycline $(10 \mu \mathrm{g})$, chloramphenicol $(30 \mu \mathrm{g})$, streptomycin $(10 \mu \mathrm{g})$, kanamycin $(30 \mu \mathrm{g})$ and erythromycin $(50 \mu \mathrm{g})$. Growth studies of wild type, cured, transformant and E. coli DH5 $\alpha$ was carried out in LB medium supplemented with varying concentration of heavy metals $2 \mathrm{mM}$ cadmium, $0.75 \mathrm{mM}$ chromium, $2.5 \mathrm{mM}$ nickel and $1.75 \mathrm{mM}$ lead. Cultures were grown separately in $25 \mathrm{~mL} \mathrm{LB}$ medium in $100 \mathrm{~mL}$ conical flasks at $37{ }^{\circ} \mathrm{C}$ for $30 \mathrm{~h}$. The growth of the bacteria was determined in terms of turbidity in the culture medium by measuring the absorbance at $600 \mathrm{~nm}$ spectrophotometerically. P. aeruginosa wild and cured type cultures were cultured in LB medium and incubated at $37^{\circ} \mathrm{C}$ with agitation for $12 \mathrm{~h}$. Cells were harvested by centrifugation at $1,200 \mathrm{~g}$ for $15 \mathrm{~min}$ at $4{ }^{\circ} \mathrm{C}$. The pellet was washed twice with sterile milliQ water. Samples for AFM analysis were mounted on cover glass and airdried as described earlier (Bolshakova et al., 2001) and mounted directly on the specimen metal disc using a double adhesive tape. Samples were scanned at different areas using AFM (Shimadzu SPM 9500-2J). For high resolution, contact mode micro cantilever was used for the analysis. Digital images were stored in the computer and processed.

\section{RESULTS AND DISCUSSION}

Contaminated environments like those in the vicinity of industries or industrial dump grounds accumulate a heavy load of toxic metal ions, organic ions, organic 
wastes and antibiotics (Haq et al., 1999). Microorganisms resistant to antibiotics and tolerant to metals appears to be the result of exposure to metal contaminated environment that cause co-incidental selection for resistance factors for heavy metals and antibiotics (Ramteke, 1997). Pseudomonas species show that resistance to a variety of toxic substances, heavy metals and antibiotics, can use various compounds as carbon sources. Hence they have generated a high degree of interest in the area of environmental bioremediation (Bruins, 2003). A variety of plasmids have been isolated from Pseudomonas species such as R-factor plasmids, which inactivate certain antibiotics and S-factor plasmids capable of initiating chromosomal gene transfer (Chakrabarty, 1976). Plasmids in Pseudomonas species are also known to code for heavy metal resistance and degradation of organic compounds (Chakrabarty, 1976). In the present study, the plasmid DNA was isolated from $P$. aeruginosa $\mathrm{BC} 15$ which revealed the presence of single plasmid and was designated as $\mathrm{pBC} 15$. The size of this plasmid was approximately $23 \mathrm{~kb}$ and $E$. coli $\mathrm{DH} 5 \alpha$ was transformed with plasmid $\mathrm{pBC} 15$.

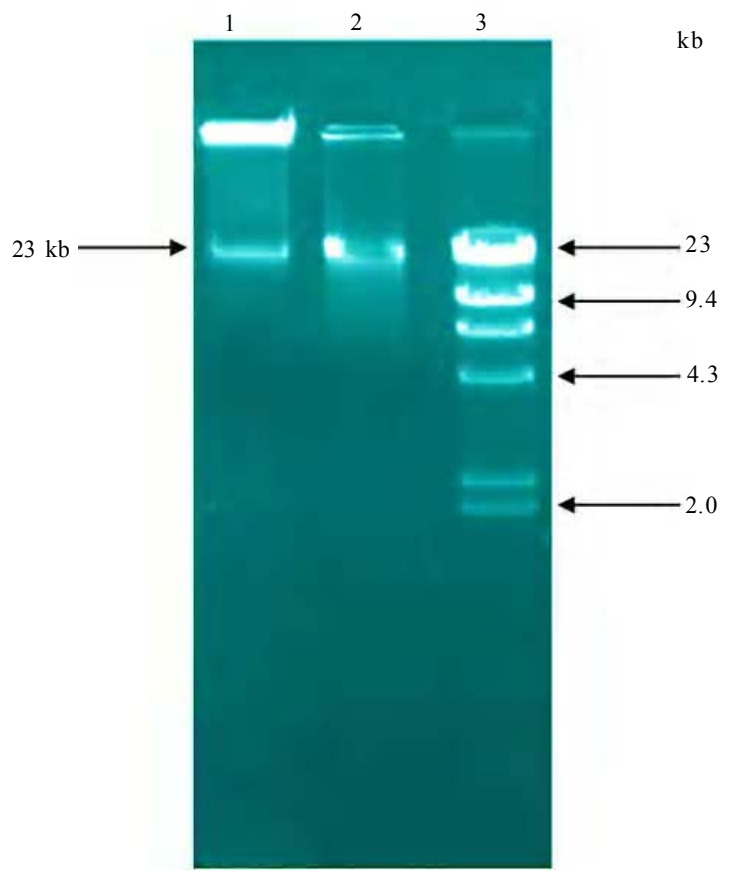

Fig. 1: Plasmid DNA profile of Pseudomonas aeruginosa BC15. Lane $1=P$. aeruginosa $\mathrm{BC} 15$ ( $\mathrm{pBc} 15)$; Lane $2=$ Transformed E. coli DH5 $\alpha$ pBC15 and Lane $3=\lambda$ Hind III digest molecular weight marker
Transformant harboured a plasmid of the same size as that in $\mathrm{BC} 15$ which is shown in Fig. 1. The similar size of plasmid DNA was identified from titanium ion resistant P. aeruginosa ATCC 10145 (Park et al., 2006) and cadmium, lead resistance Pseudomonas species S8A isolated from mine tailing contaminated soil (Kassab and Roane, 2006). The restriction analysis profile showed that the plasmid DNA has one site for Bam HI, Eco RI and three sites for Xho I exhibited by three fragments corresponds to $11.5 \mathrm{~kb}, 7.5 \mathrm{~kb}$ and $5 \mathrm{~kb}$ positions of the $1 \mathrm{~kb}$ DNA marker. The aggregate of the fragments in Bam HI, Eco RI and Xho I was approximately $23 \mathrm{~Kb}$ and $23.5 \mathrm{~kb}$, respectively. Therefore, the plasmid DNA of $P$. aeruginosa $\mathrm{BC} 15$ was approximately $23 \mathrm{~kb}$ (Fig. 2). Curing of plasmid was carried out with ethidium bromide, acridine orange, novobiocin, SDS and temperature at $40{ }^{\circ} \mathrm{C}$ (Fig. 3). Plasmid curing was achieved only by growing the strain treatment with SDS while other curing agents and temperature at $40{ }^{\circ} \mathrm{C}$ were not effective. A plasmid containing $E$. coli strain was treated with $10 \%$ SDS leads to loss of a plasmid. The plasmid elimination was accompanied by drastic changes in antibiotic resistance

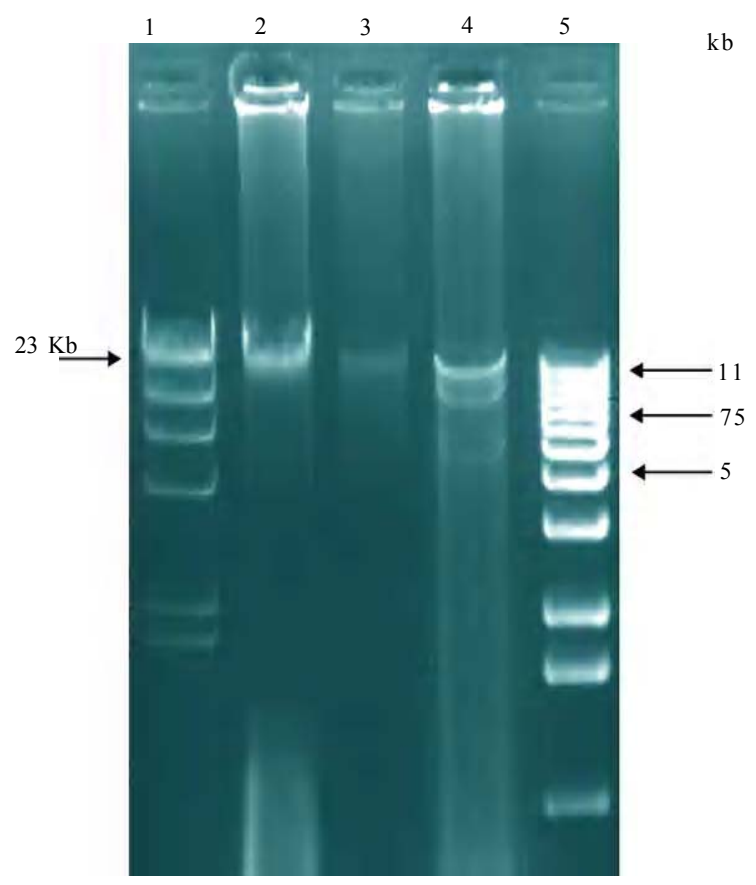

Fig. 2: Restriction analysis of $P$. aeruginosa BC15 plasmid DNA. Lane $1=\lambda$ Hind III digest; Lane $2=$ Bam HI digest; Lane 3 =Eco RI digest; Lane $4=$ Xho I digest and Lane $5=1 \mathrm{~kb}$ DNA ladder 


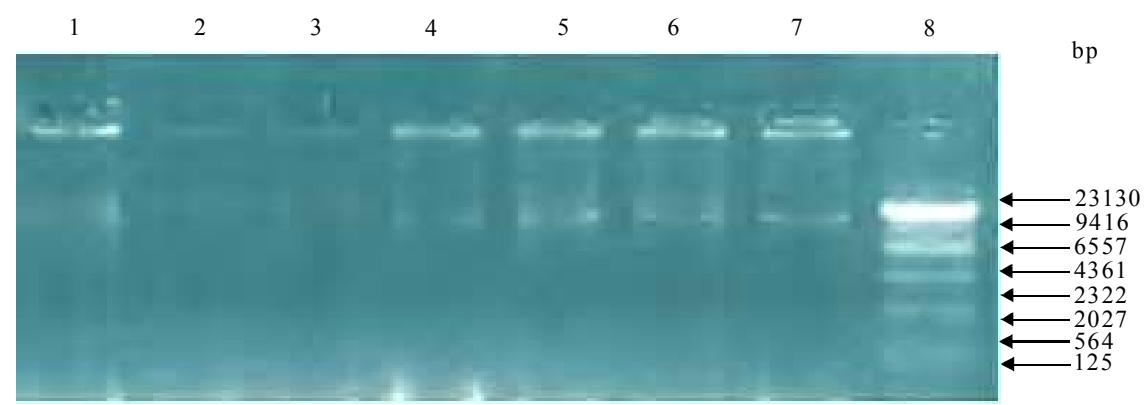

Fig. 3: Effect of curing agents on $\mathrm{BC} 15$ plasmid. Lane $1=\mathrm{BC} 15$ plasmid DNA; Lane $2=$ SDS cured 1; Lane $3=\operatorname{SDS}$ cured 2; Lane $4=$ Ethidium bromide $(\mathrm{EtBr})$ cured; Lane $5=$ Acridine orange $(\mathrm{AO})$ cured; Lane $6=$ Novobiocin (NB) cured; Lane $7=$ Temperature at $40{ }^{\circ} \mathrm{C}$ and Lane $8=\lambda$ Hind III digest molecular weight marker

Table 1: Antibiotic sensitivity of $P$. aeruginosa $\mathrm{BC} 15$

\begin{tabular}{lcccc}
\hline Antibiotics $(\mu \mathrm{g} /$ disc) & BC15 (wild type) & BC15 (cured) & Transformant & DH5 $\alpha$ \\
\hline Ampicillin (10) & $\mathrm{R}$ & $\mathrm{S}$ & $\mathrm{R}$ & $\mathrm{S}$ \\
Tetracycline (10) & $\mathrm{R}$ & $\mathrm{S}$ & $\mathrm{S}$ & $\mathrm{S}$ \\
Chloramphenicol (30) & $\mathrm{R}$ & $\mathrm{S}$ & $\mathrm{S}$ & $\mathrm{S}$ \\
Streptomycin (10) & $\mathrm{R}$ & $\mathrm{S}$ & $\mathrm{S}$ & $\mathrm{S}$ \\
Kanamycin (30) & $\mathrm{R}$ & $\mathrm{S}$ & $\mathrm{S}$ & $\mathrm{S}$ \\
Erythromycin (50) & $\mathrm{R}$ & $\mathrm{S}$ & & \\
\hline
\end{tabular}

Note: R-resistant; S-sensitive

and morphology of the colonies (Rosas, 1983). The antibiotic resistance pattern of wild type, cured, transformant and E. coli DH5 $\alpha$ were described in Table 1. This pattern revealed that wild type $\mathrm{BC} 15$ and transformant were resistant to ampicillin. On the other hand, cured and E. coli DH5 $\alpha$ were sensitive to ampicillin. From this data, the genes encoding resistance to ampicillin are located on the plasmid $\mathrm{pBC} 15$. Furthermore, wild type $\mathrm{BC} 15$ was resistant to tetracycline, chloramphenicol, streptomycin, kanamycin and erythromycin. But cured strain was sensitive to these antibiotics indicating the possible plasmid borne nature of genes encoding resistance to these antibiotics. However, transformant did not develop resistance to these antibiotics in spite of acquiring the plasmid $\mathrm{pBC} 15$. This suggested that loss of antibiotic resistance phenotype in cured strain may be either because of mutation as a result of incubation in the presence of the curing or genes encoding resistance to the above antibiotics are not transferred to E. coli. Chromosome and plasmid encoded metal resistance genetic systems have been studied in Pseudomonas, as well as in related bacteria (Cervantes, 1996). Pseudomonas species resistant to cadmium up to 1.2
$\mathrm{mM}$ maximum tolerable concentration was isolated from heavy metal contaminated soil (Roane and Kellogg, 1996). P. aeruginosa BC15 resistant to cadmium up to $6 \mathrm{mM}$ in LB agar plates (data not shown). The growth studies of $P$. aeruginosa $\mathrm{BC} 15$ at different concentrations of metals cadmium, chromium, nickel and lead in LB medium is shown in Figs. 4 a, b, c, and d. The measurements of the culture incubated for $30 \mathrm{~h}$ were in good agreement with bacterial resistance for each metal. When strains were grown in cadmium supplemented media, wild type and cured type exhibited maximum peak value, but no growth was observed from transformant and E. coli DH5 $\alpha$. In the presence of nickel, wild type and transformant exhibited maximum peak values. Growth of $P$. aeruginosa $\mathrm{BC} 15$ in the presence of chromium wild type and cured were exhibited maximal peak value compared to transformant and E. coli DH5a. The growth of all strains in the presence of lead indicates that there is no change in the growth pattern. From the results, it is cleared that wild type and transformant were resistant to nickel, in contrast the cured derivative and E. coli DH5 $\alpha$ were sensitive to nickel. The above results indicate that the plasmid can replicate in E. coli DH5a for nickel 

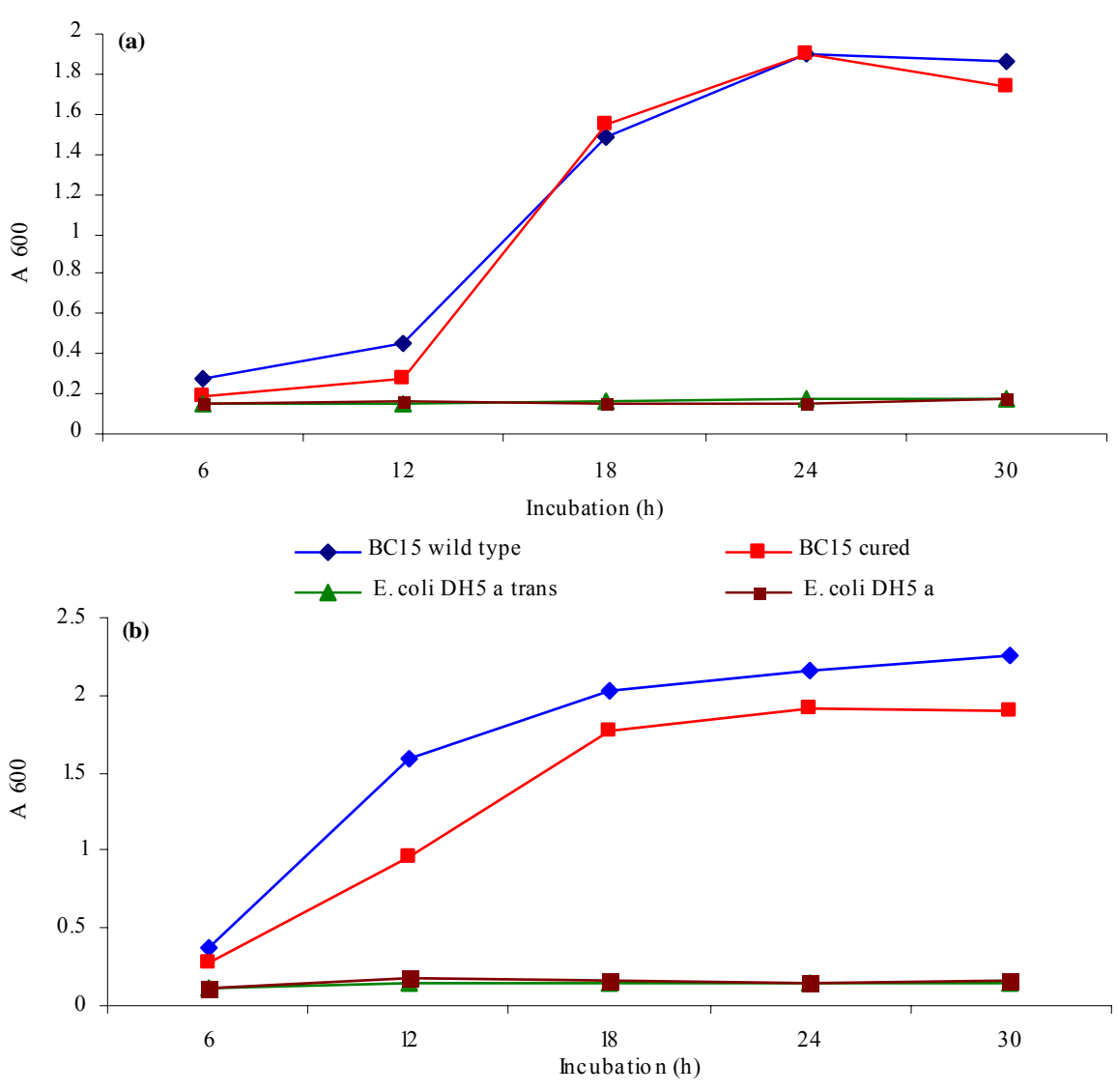

$$
\begin{array}{ll}
\longrightarrow \text { BC } 15 \text { wild type } & \longrightarrow \text { BC } 15 \text { cured } \\
\longrightarrow \text { E.coliDH5 a trans } & \longrightarrow \text { E.coliDH5 a }
\end{array}
$$

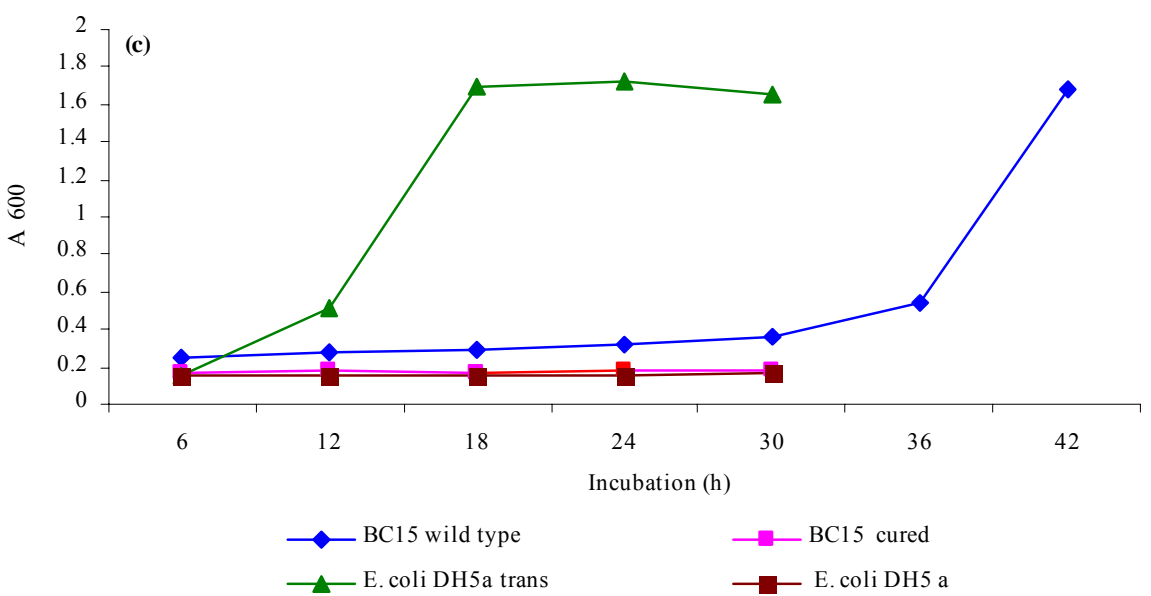

Fig. 4: Growth studies of wild type, cured, transformant and E. coli DH5 $\alpha$ in LB medium supplemented with $2 \mathrm{mM}$ cadmium (a), $0.75 \mathrm{mM}$ chromium (b), $2.5 \mathrm{mM}$ nickel (c) $1.75 \mathrm{mM}$ lead and (d) incubated at $37{ }^{\circ} \mathrm{C}$ for $30 \mathrm{~h}$ 


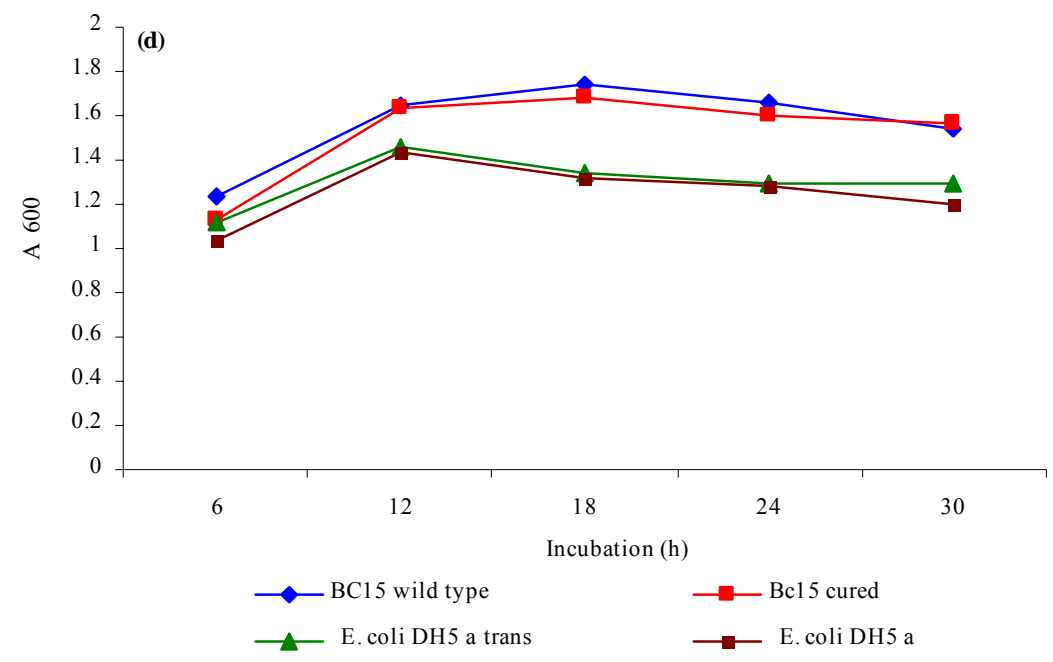

Fig. 4 (continued): Growth studies of wild type, cured, transformant and E. coli DH5 $\alpha$ in LB medium supplemented with $2 \mathrm{mM}$ cadmium (a), $0.75 \mathrm{mM}$ chromium (b), $2.5 \mathrm{mM}$ nickel (c) $1.75 \mathrm{mM}$ lead and (d) incubated at $37{ }^{\circ} \mathrm{C}$ for $30 \mathrm{~h}$
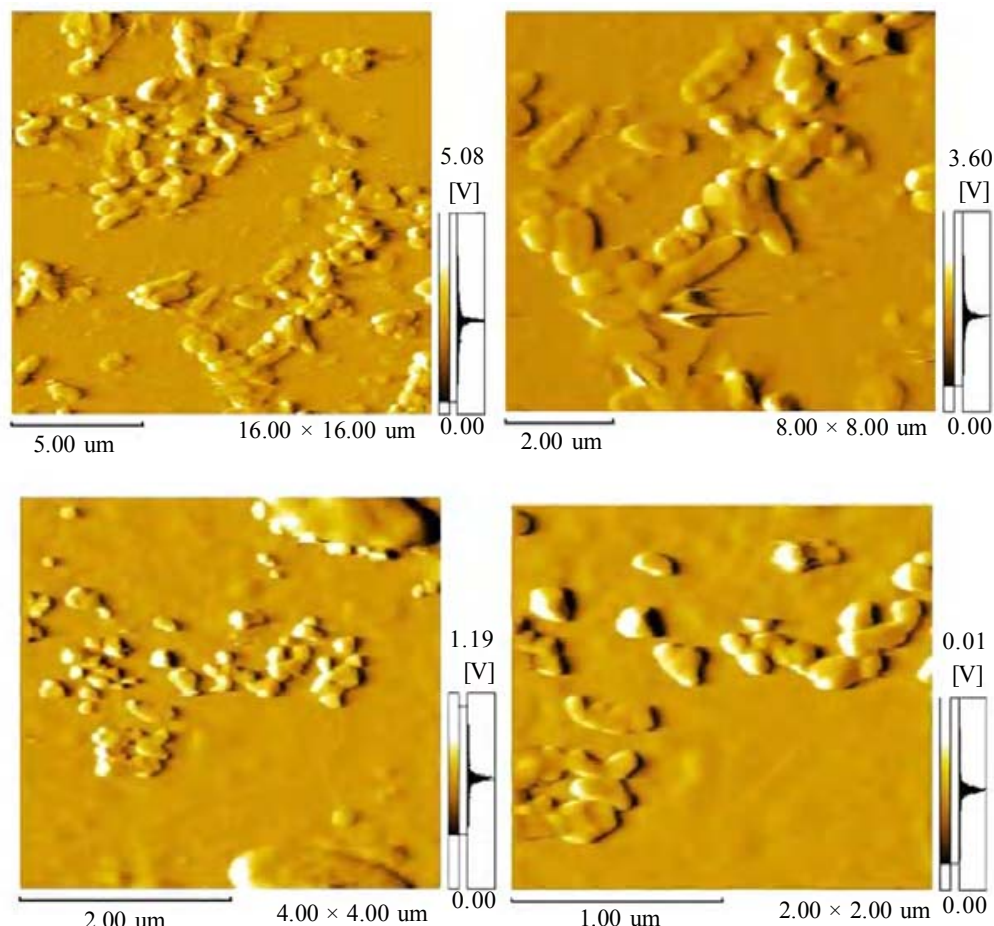

Fig. 5: Atomic force micrographs of P. aeruginosa on: (A) wild type; (B) cured type cells

resistance. Therefore, it is evident that genes encoding resistance to ampicillin and nickel were located on plasmid pBC15. Similar result obtained from
Pseudomonas species was isolated from water and soil samples (Unaldi et al., 2003). The wild type BC15 and cured type cultures were imaged with AFM operated 
in contact mode liquid conditions (Fig. 5). The wild type $\mathrm{BC} 15$ was yellowish brown in colour whereas the colony of the cured strain was white in colour and also smaller in size compared to wild type. Moreover, colonies of the wild type BC15 strain was raised, but the cured strain exhibited flat colonies. A similar finding was observed from a plasmid borne determinant of Pseudomonas species that was isolated from leaf of cotton (Saha, 2001). Transformation and curing results of the study suggested that nickel and ampicillin resistance were conferred by plasmid DNA, while cadmium, chromium and lead resistance seems to be encoded by genes of the bacterial chromosome. The development of the metal resistant population in a contaminated soil can result from vertical gene transfer (reproduction), horizontal gene transfer, including transposons and broad host range plasmids and selection pressures on spontaneous mutants due to the presence of heavy metals (Bogdanova, 1998). Transformation of nickel resistance gene suggests that horizontal gene transfer may be an important factor for the development of metal resistant populations in the environment. Indeed, further studies have to be performed to elucidate bioremediation of heavy metals and detoxification processes operating in this system.

\section{ACKNOWLEDGMENTS}

One of the authors (C. Edward Raja) would like to thank the University Grants Commission (UGC) for providing the Meritorious Fellowship for Bio-Sciences.

\section{REFERENCES}

Ajmal, M.; Mohammad, A.; Yousuf, R.; Ahmad, A., (1998). Adsorption behaviour of cadmium, zinc, nickel and lead from aqueous solution by Mangifera indica seed shell. Indian J. Environ. Health., 40 (1), 5-26 (22 pages).

Asmatullah, Q. S. N.; Shakoori, A. R., (1998). Hexavalent chromium-induced congenital abnormalities in chick embryos. J. Appl. Toxicol., 18 (3), 167-171 (5 pages).

Babich, H.; Stotzky, G., (1983). Toxicity of nickel to microbes: Environmental aspects. Adv. Appl. Microbiol., 29 (1), 195265 (71 pages)

Banjerdkij, P.; Vattanaviboon, P.; Mongkolsuk, S., (2005). Exposure to cadmium elevates expression of genes in the oxy $\mathrm{R}$ and $\mathrm{Ohr} \mathrm{R}$ regulons and induces cross-resistance to peroxide killing treatment in Xanthomonas campestris. Appl. Environ. Microbiol., 71 (4), 1843-1849 (7 pages).

Bauer, A. W.; Kirby, W. M. M.; Sherris, J. C.; Turck, M., (1966). Antibiotic susceptibility testing by a standardized single disc method. Am. J. Clin. Pathol., 45 (4), 493-496 (7 pages).

Bogdanova, E. S.; Bass, I. A.; Minakhin, L. S.; Petrova, M. A.; Mindin, S. Z.; Volodin, A. A.; Kalyaeva, E. S.; Tiedje, G. M.;
Hobman, J. L.; Brown, N. L.; Nikiforov, V. G., (1998). Transfer of mer operons amongest environmental isolates of gram-positive bacteria. Microbiology, 144 (3), 609-620 (12 pages)

Bolshakova, A. V.; Kiselyova, O. I.; Filonov, A. S.; Frolova, O.; Yu Lyubchenko Yu, L.; Yaminsky, I. V., (2001). Comparative analysis of bacteria with atomic force microscopy operating in different modes. Ultra Microscopy, 68 (1-2), 121-128 (8 pages).

Bruins, M. R.; Kapil, S.; Oehme, F. W., (2003). Characterization of a small plasmid (pMBCP) from bovine Pseudomonas pickettii that confers cadmium resistance. Ecotox. Environ. Safe., 54 (3), 241-248 (8 pages).

Cervantes, C.; Silver, S., (1996). Metal resistance systems in Pseudomonas. Rev. Latin. Microbiol., 38 (1), 45-64 (20 pages).

Chakrabarty, A. M., (1976). Plasmids in Pseudomonas. Annu. Rev. Gen., 10, 7-30 (24 pages).

Chen, C. Y.; Lin, T. H., (1998). Nickel toxicity to human term placenta: In vitro study on lipid per oxidation. J. Toxicol. Env. Health., Part A, 54 (1), 37-47 (11 pages).

Collard, J. M.; Corbisier, P.; Diels, L.; Dong, Q.; Jeanthon, C.; Mergeay, M.; Taghavi, S.; Vander Lelie, D.; Wilmotte, A.; Wuertz, S., (1994). Plasmids for heavy metal resistance in Alcaligenes eutrophus $\mathrm{CH} 34$ : Mechanism and applications. FEMS Microbiol. Rev., 14 (4), 405-414 (10 pages).

Ebdon, L.; Pitts, I.; Cornelis, R.; Crews, H.; Donard, O. F. X.; Quevauviller, P., (2001). Trace element speciation for environment, food and health. Cambridge UK: Royal society of chemistry, ISBN 0854044590

Edward Raja, C.; Anbazhagan, K.; Selvam, G. S., (2006). Isolation and characterization of a metal-resistant Pseudomonas aeruginosa strain. World J. Microbiol. Biotechnol., 22 (6), 577-585 (9 pages).

Haq, R.; Zaidi, S. K.; Shakoori, A. R., (1999). Cadmium resistant Enterobacter cloacae and Klebsiella sp. isolated from industrial effluents and their possible role in cadmium detoxification. World J. Microbiol. Biotech., 15 (2), 249254 (6 pages).

Jin, Y. A.; Clark, A. B.; Slebos, R. J.; AL-Refai, H.; Taylor, J. A.; Kunkel, T. A.; Resnick, M. A.; Gordenin, D. A., (2003). Cadmium is a mutagen that acts by inhibiting mismatch repair. Nat. Genet., 34 (3), 239-241 (3 pages).

Kassab, D. M.; Roane, T. M., (2006). Differential responses of a mine tailings Pseudomonas isolate to cadmium and lead exposures. Biodegradation, 17 (4), 379-387 (9 pages).

Low, K. S.; Lee, C. K.; Liew, S. C., (2000). Sorption of Cadmium and Lead form aqueous solution by spent grain. Proc. Biochem., 36 (1-2), 59-64 (6 pages).

Mesas, J. M.; Carmen-Rodriguez, M.; Teresa Alegrec, T. M., (2004). Plasmid curing of Oenococcus oeni. Plasmid, 51 (1), 37-40 (4 pages).

Mulrooney, S. B.; Hausinger, R. P., (2003). Nickel uptake and utilization by microorganisms. FEMS Microbiol. Rev., 27 (2-3), 239-261 (23 pages).

Nies, D. H., (2003). Efflux mediated heavy metal resistance in prokaryotes. FEMS Microbiol. Rev. 27 (2-3), 313-339 (27 pages).

Park, S. M.; Kim, S. H.; Yu, T. S., (2006). Effect of titanium ion and resistance encoding plasmid of Pseudomonas aeruginosa ATCC 10145. J. Microbiol., 44 (3), 255-262 (8 pages). 
Prasad, M. N. V.; Strazalka, K., (2000). In: Physiology and biochemistry of metal toxicity and tolerance in plants, Kluwer Academic Publishers, Boston, 153-160.

Prasenjit, B.; Sumathi, S., (2005). Uptake of chromium by Aspergillus foetidus. J. Mat. Cyc. Waste Manage., 7 (2), 8892 (5 pages).

Ramteke, P. W., (1997). Plasmid mediated co-transfer of antibiotic resistance and heavy metal tolerance in coli forms. Indian J. Microbiol., 37, 177-181 (5 pages).

Rensing, C.; Sun, Y.; Mitra, B.; Rosen, B. P., (1998). Pb (II) translocating P-type ATPases. J. Biol. Chem., 273 (49), 32614-32617 (4 pages).

Roane, T. M.; Kellogg, S. T., (1996). Characterization of bacterial communities in heavy metal contaminated soils. Can. J. Microbiol., 42 (6), 593-603 (11 pages).

Romling, U.; Wingender, T.; Muller, H.; Tummler, B., (1994). A major Pseudomonas aeruginosa clone common to patients and aquatic habitats. Appl. Environ. Microbiol., 60 (6), 1734-1738 (5 pages).

Rosas, S. B.; Calzolari, A.; La Torre, J. L.; Ghittoni, N. E.; Vasquez, C., (1983). Involvement of a plasmid in Escherichia coli envelope alterations. J. Bacteriol., 155 (1), 402-406 (5 pages).
Rossello-Mera, A. R.; Lalucat, J.; Garcia-Valdes, E., (1994). Comparative biochemical and genetic analysis of naphthalene degradation among Pseudomonas stutzeri strains. Appl. Environ. Microbiol., 60 (3), 966-972 (7 pages).

Saha, S.; Singh, R. P.; Verma, J. P.; Jayaraman, J., (2001). Plasmid-borne determinants of colony morphology, pigmentation, antibiotic resistance and antibiosis in Pseudomonas species antagonistic to bacterial blight of cotton. Curr. Sci., 79 (9), 1384-1385 (2 pages).

Sambrook, J.; Fritsch, E. F.; Maniatis, T., (1989). Molecular cloning: A laboratory manual, $2^{\text {nd. }}$ Ed. Cold spring harbour, NY: Cold spring harbour laboratory press.

Shumilla, A. J.; Broderick, J. R.; Wang, Y.; Barchowsky, A., (1999). Chromium Cr (VI) inhibits the transcriptional activity of nuclear factor-B by decreasing the interaction of p65 with cAMP-responsive element binding protein. J. Biol. Chem., 274 (51), 36207-36212 (6 pages).

Unaldi, M. N.; Korkmaz, H.; Ankan, B.; Corel, G., (2003). Plasmid-encoded heavy metal resistance in Pseudomonas sp. Bull. Environ. Contam. Toxicol., 71 (6), 1145-1150 (6 pages).

\section{AUTHOR (S) BIOSKETCHES}

Edward Raja, C., M.Sc., Ph.D. research student, Department of Biochemistry, Center for Excellence in Genomic Sciences, School of Biological Sciences, Madurai Kamaraj University, Madurai- 625 021, India. Email: edwardrajac@gmail.com

Selvam, G. S., M.Sc., M. Phil., Ph.D., Full professor, Department of Biochemistry, Center for Excellence in Genomic Sciences, School of Biological Sciences, Madurai Kamaraj University, Madurai-625 021, India. Email: drselvamgsbiochem@rediffmail.com

This article should be referenced as follows:

Edward Raja, C.; Selvam, G. S., (2009). Plasmid profile and curing analysis of Pseudomonas aeruginosa as metal resistant. Int. J. Environ. Sci. Tech., 6 (2), 259-266. 